\title{
TIPOLOGI RUANG DAN WUJUD ARSITEKTUR MASJID TRADISIONAL KALIMANTAN SELATAN
}

\author{
Naimatul Aufa
}

\author{
Jurusan Arsitektur Universitas Lambung Mangkurat \\ Banjarmasin, Kalimantan Selatan, Indonesia \\ e-mail: aufaheldi@yahoo.co.id
}

\begin{abstract}
These days, many researches on traditional architecture of South Kalimantan focus merely on traditional settlements and houses. Particularly, the research on places of worship has been conducted in small numbers, and it is sometimes never publicized, especially in scientific magazine or journal. Meanwhile, the construction of some new mosques in South Kalimantan has no longer concerned the local architecture. This research alone aims to attain architecture's entity as the place of worship for the people of South Kalimantan, especially for Banjarese Tribe as the majority in South Kalimantan. Traditional Banjarese Tribe is known as an islamic tribe. They used to be called Dayak Tribe since they had faith in traditional religions such as animism and dynamism. As Muslim people, they perform their prayers in a place of worship called mesigid (mosque). The research applies the method of case study. Based on the result of field and literature study, the architecture entity of Banjarese's place of worship has some specific features that are different from other mosques in other regions. From the analyses, it can be concluded that the traditional mosques of South Kalimantan have three kinds of room, which are palataran, praying area, and mihrab (a chamber indicating the direction of Mecca). Palataran is the porch or the terrace surrounding the mosque, while the praying area and mihrab are rectangular. Traditional mosques in South Kalimantan have their own entity which is formed by the plan of praying area and mihrab, as well as their three layered-roof. The roof in these mosques has a sharp angle $\left(60^{\circ}\right)$ and an acute angle $\left(20^{\circ}\right)$. Furthermore, the overall entity of the mosque symbolizes hayat tree (Dayak Tribe), and the ornaments (pataka/patala) found on the roof top is a symbol of hornbill. Both symbols are the symbols of identity and mythology of Dayak Tribe.
\end{abstract}

Keywords: Typology of space, typology of entity, traditional mosque of South Kalimantan

\begin{abstract}
Abstrak
Selama ini penelitian tentang arsitektur tradisional Kalimantan Selatan terfokus pada permukiman dan rumah tradisional saja. Khusus untuk bangunan ibadah jarang sekali dilakukan, kalaupun ada penelitian yang dilakukan hampir tidak pernah dipublikasikan, khususnya di majalah/jurnal ilmiah. Sementara itu, pembangunan masjidmasjid baru di Kalimantan Selatan sudah tidak mempertimbangkan arsitektur lokal. Adapun penelitian ini sendiri, bertujuan untuk mendapatkan wujud arsitektur sebagai tempat ibadah masyarakat Kalimantan Selatan, khususnya Suku Banjar sebagai masyarakat mayoritas di Kalimantan Selatan. Suku Banjar Tradisional dikenal sebagai pemeluk Agama Islam, karena jika masih memeluk agama tradisional (animisme/dinamisme), maka masyarakat ini tidak akan disebut sebagai Suku Banjar, melainkan Suku Dayak. Seperti pada umumnya umat muslim, tempat beribadah Suku Banjar disebut dengan mesigid (masjid). Penelitian ini menggunakan metode studi kasus. Berdasarkan hasil studi lapangan dan kepustakaan, diperoleh kesimpulan bahwa wujud arsitektur tempat ibadah Suku Banjar memiliki ciri-ciri khusus yang membedakannya dengan wujud masjid-masjid lainnya. Dari hasil analisis diperoleh gambaran bahwa masjid tradisional Kalimantan Selatan memiliki tiga jenis ruang, yaitu palataran (teras keliling), tempat sholat, dan mihrab. Palataran berupa teras keliling, sedangkan denah shalat dan mihrab berbentuk persegi. Masjid tradisional Kalimantan Selatan memiliki wujud sendiri yang dibentuk oleh denah ruang shalat dan mihrab, serta atap bertumpang tiga. Atap pada masjid tradisional Kalimantan Selatan memiliki sudut runcing $\left(60^{\circ}\right)$ dan sudut tumpul $\left(20^{\circ}\right)$. Selain itu, wujud masjid keseluruhan merupakan simbolisasi dari pohon hayat (Suku Dayak), dan di puncak atas atap ditemukan hiasan (pataka/patala) yang merupakan simbol dari Burung Enggang. Kedua simbol ini merupakan simbol identitas dalam mitologi Suku Dayak.
\end{abstract}

Kata kunci: Tipologi wujud, tipologi ruang, masjid tradisional Kalimantan Selatan

\section{Pendahuluan}

Suku Banjar di Kalimantan Selatan dikenal sebagai pemeluk agama Islam. Sejarah menyebutkan bahwa Islam masuk ke Kalimantan Selatan sejak mulai berdirinya Kerajaan Banjar, yaitu pada tahun
1525 Masehi. Walaupun demikian, temuan para sejarawan dan arkeolog di Kabupaten Tapin, salah satu kabupaten di propinsi ini, menunjukkan kenyataan yang berbeda. Dinyatakan oleh beberapa sejarawan dan arkeolog, bahwa Islam masuk ke 
Kalimantan Selatan jauh sebelum Kerajaan Banjar berdiri.

Seperti umumnya umat muslim di dunia, Suku Banjar juga memiliki masjid sebagai tempat mereka beribadah. Masjid sebagai tempat beribadah umat muslim memiliki wujud arsitektur yang berbeda di tiap-tiap wilayah. Utaberta mengungkapkan bahwa masjid di dunia memiliki tipologi yang berbedabeda'. Tipologi masjid di dunia menurut Utaberta adalah sebagai berikut:

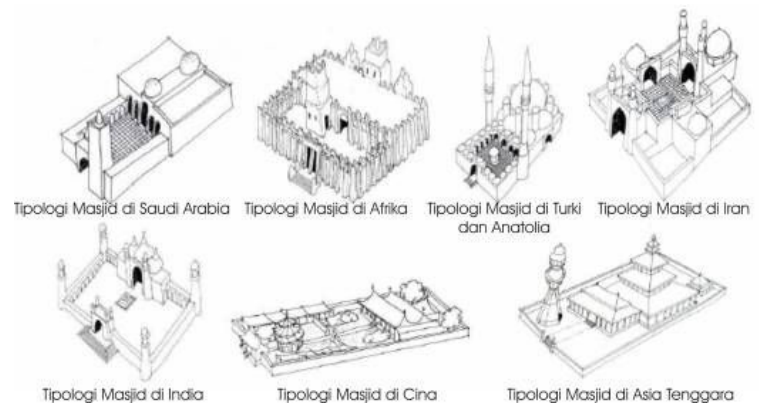

Gambar 1. Berbagai bentuk tipologi masjid di berbagai negara (Sumber: Utaberta, 2004)

Masjid tradisional adalah masjid yang dibangun sejak jaman masuknya Islam pertama kali dan memiliki bentuk (langgam) yang disesuaikan dengan situasi dan kondisi pada masa itu, serta dilatarbelakangi oleh pola pikir masyarakat yang merupakan tradisi setempat. Bambang Setia Budi menegaskan di akhir penelitiannya tentang arsitektur tradisional Jawa, bahwa hasil penelitiannya tidak bisa digeneralisasi untuk semua bentuk bangunan tradisional di Indonesia, karena masing-masing daerah di Indonesia memiliki karakteristik yang berbeda, tergantung dari budaya lokal yang membentuknya ${ }^{2}$. Hal inilah yang melandasi pemikiran bahwa masjid tradisional Kalimantan Selatan memiliki bentuk tersendiri yang membedakannya dengan masjid lainnya di Indonesia dan di dunia.

Permasalahannya sekarang adalah mengenai bentuk masjid tradisional Kalimantan Selatan saat ini. Hal ini penting untuk diketahui, mengingat banyaknya pembangunan masjid di Kalimantan Selatan yang tidak mempertimbangkan arsitektur lokal sebagai dasar perancangannya. Masjid Sabilal Muhtadin sebagai ikon Kota Banjarmasin yang merupakan ibukota Propinsi Kalimantan Selatan juga tidak mencerminkan arsitektur lokal Kalimantan Selatan tersebut.

Arsitektur masjid tradisional Kalimantan Selatan juga penting untuk diketahui mengingat adanya rencana Pemerintah Propinsi Kalimantan Selatan untuk merekonstruksi Keraton Banjar. Masjid merupakan salah satu bagian yang penting dari keraton tersebut. Selama ini, bangunan masjid belum menjadi fokus utama dalam penelitianpenelitian yang dilakukan untuk merekonstruksi
Keraton Banjar. Penelitian tahun 2006 oleh Kasnowihardjo, Muchammad, dan Aufa mengenai rekontruksi Keraton Banjar terbatas pada bangunan istana saja. Penelitian tahun 2009 oleh Balitbangda Propinsi Kalimantan Selatan terfokus pada upaya pencarian rencana lokasi pembangunan Keraton Banjar. Di akhir tahun 2009, sebagai lanjutan dari penelitian sebelumnya, penelitian oleh Muchammad hanya terfokus pada tipologi ruang dan bentuk istana dari Kerajaan Banjar. Jadi, studi tentang wujud arsitektur masjid tradisional Kalimantan Selatan hampir tidak pernah dilakukan, sementara rencana rekonstruksi Keraton Banjar mencakup kompleks istana yang bangunannya tidak hanya terdiri dari istana raja saja, melainkan juga bangunan-bangunan lainnya termasuk masjid. Untuk itu, penelitian ini bertujuan untuk melengkapi penelitian-penelitian sebelumnya tentang wujud arsitektur masjid tradisional Kalimantan Selatan.

Penelitian ini menggunakan paradigma penelitian naturalistik - kualitatif. Untuk mengetahui tipologi ruang dan wujud masjid tradisional Kalimantan Selatan, digunakan metode studi kasus. Metode ini dilakukan dengan mempelajari kasuskasus yang ditemukan di lapangan. Kemudian, temuan-temuan yang diperoleh di lapangan tersebut dibandingkan dengan data-data kepustakaan (studi literatur, termasuk penelitian-penelitian terkait), sehingga diperoleh gambaran tentang tipologi ruang dan wujud masjid tradisional Kalimantan Selatan yang tepat.

Adapun penentuan lokasi masing-masing kasus ditentukan berdasarkan lokasi dimana pernah ditemukannya jejak Keraton Banjar di Kalimantan Selatan. Hal ini dilakukan karena Islam di Kalimantan Selatan umumnya disebarkan oleh ulama yang berasal dari Kerajaan Banjar. Jadi, secara tidak langsung masjid-masjid yang menjadi kasus dalam penelitian ini juga memiliki keterkaitan dengan Kerajaan Banjar.

Setelah lokasi ditentukan, maka langkah selanjutnya adalah pemilihan kasus penelitian, penentuan kasus-kasus penelitian didasarkan atas syarat-syarat sebagai berikut:

a. Usia masjid termasuk kategori Benda Cagar Budaya (> 50 tahun), dan hal ini sesuai dengan pengertian masjid tradisional sebagai masjid tua yang diturunkan dari generasi ke generasi.

b. Wujud masjid masih mencerminkan masjid tradisional, yaitu berbahan baku kayu dan beratap tumpang meskipun telah mengalami beberapa kali rehabilitasi.

c. Sejarah masjid masih terkait dengan keberadaan Keraton Banjar.

Berdasarkan ketiga kriteria di atas, maka terpilih tujuh kasus yang akan diteliti dalam penelitian ini. Gambar 2 dan Gambar 3 berikut adalah ketujuh kasus masjid yang memenuhi ketiga 
kriteria tersebut, beserta lokasinya di dalam wilayah penelitian.

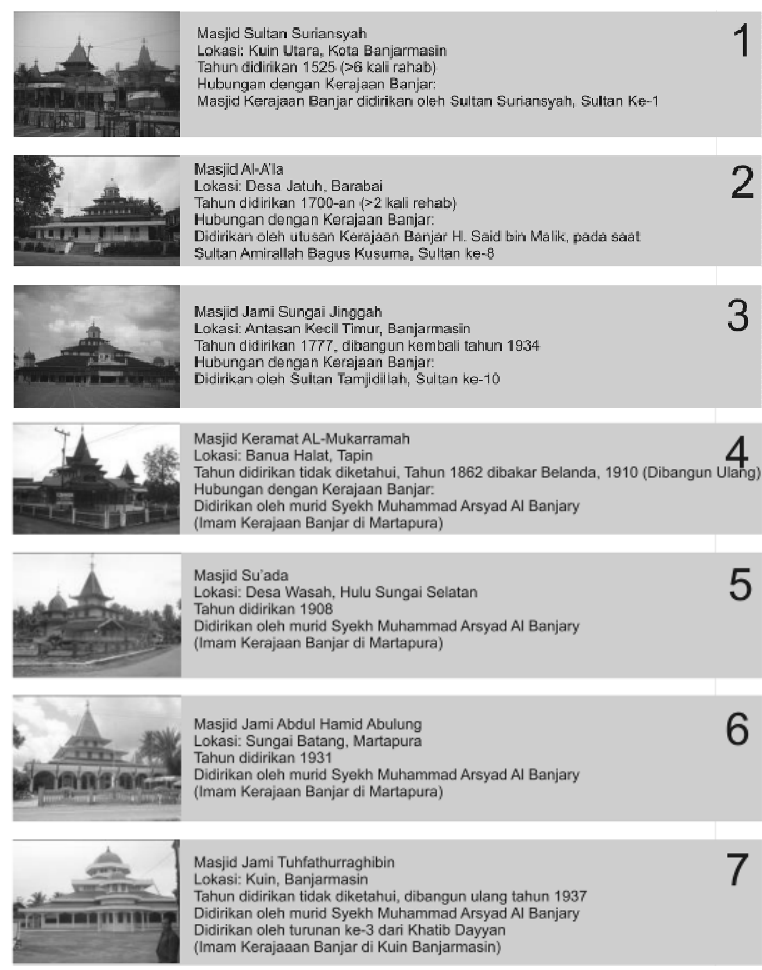

Gambar 2. Kasus-Kasus Penelitian (Sumber: Hasil Survey, 2009)

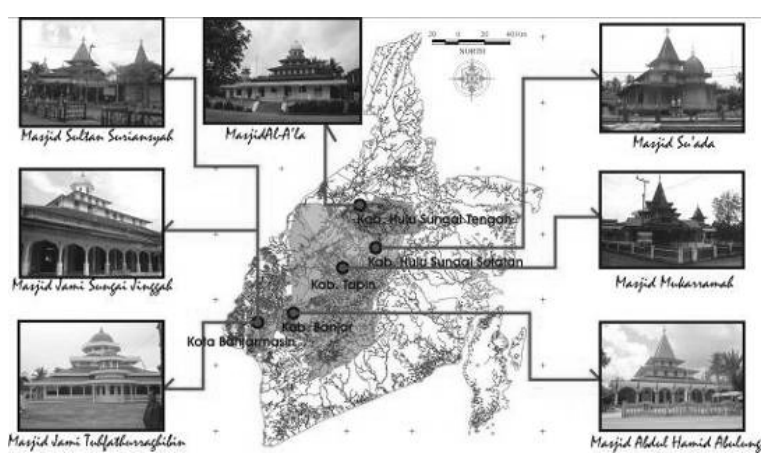

Gambar 3. Kasus Penelitian dan Lokasi Kasus pada Wilayah Studi (Sumber: Hasil Survey, 2009)

\section{Sejarah Masjid di Kalimantan Selatan}

Sejarah masjid di Kalimantan Selatan atau di berbagai daerah lainnya di muka bumi ini tak lepas dari sejarah perkembangan Islam di wilayah yang bersangkutan. Dengan menelusuri rekam sejarah kerajaan yang pernah berdiri di Kalimantan Selatan, maka diketahui bahwa Islam masuk ke wilayah ini sejak berdirinya Kerajaan Banjar di sebuah tempat yang bernama Kuin. Kerajaan Banjar merupakan penerus Kerajaan Daha yang beragama Hindu. Kerajaan Daha sendiri merupakan penerus Kerajaan Dipa yang beragama Budha. Dengan demikian, dapat diketahui bahwa Kerajaan Banjar adalah Kerajaan Islam pertama di Kalimantan Selatan.

Kerajaan Banjar didirikan pada tahun 1525 Masehi. Pada saat pertama kali berdiri, kerajaan ini dipimpin oleh Sultan Suriansyah. Pada masa kekuasaan Kerajaan Banjar, dibangun masjid pertama di Kalimantan Selatan. Masjid ini direncanakan oleh Aria Malangkang, seorang ahli bangunan utusan Kerajaan Demak. Masjid ini diberi nama Masjid Sultan Suriansyah. Imam pertama masjid ini adalah seorang ahli perang dari Kerajaan Demak yang bernama Khatib Dayyan, konon beliau merupakan cucu Sunan Gunung Jati. Setelah Demak berhasil membantu Pangeran Samudera (Sultan Suriansyah) merebut kembali kekuasaan dan mendirikan Kerajaan Banjar serta Masjid Sultan Suriansyah, Khatib Dayyan kemudian diangkat menjadi Imam Masjid Sultan Suriansyah. Tugas ini terus dipegang dan dijalankan. Anak cucunya pun meneruskannya hingga sekarang.

Masjid Sultan Suriansyah terletak kira-kira 300 meter ke arah timur dari Kompleks Makam Sultan Suriansyah. Muchammad meyakini bahwa Kompleks Makam Sultan Suriansyah merupakan pusat pemerintahan Kerajaan Banjar (Keraton Banjar) ${ }^{3}$.

Saat Belanda menjajah bumi Kalimantan Selatan, wilayah Keraton Banjar dibumihanguskan, khususnya kompleks Keraton Banjar. Tidak ditemukan informasi apakah pada saat pembakaran itu Masjid Sultan Suriansyah juga ikut terbakar. Sejak itu, pusat Kerajaan Banjar berpindah-pindah (masih dalam wilayah Kalimantan Selatan), dan masjidmasjid mulai berdiri di lokasi-lokasi yang pernah disinggahi oleh orang-orang dari Kerajaan Banjar, termasuk di daerah yang menjadi lokasi kasus penelitian ini.

\section{Fungsi Masjid Tradisional Kalimantan Selatan} berikut:

Menurut Gazalba ${ }^{4}$, fungsi masjid adalah sebagai

a. Sebagai tempat untuk kegiatan ibadah, yaitu (1) sebagai tempat melaksanakan sholat fardhu dan sholat sunah, (2) sebagai tempat melaksanakan zakat, (3) sebagai tempat kegiatan penunjang ibadah puasa di bulan Ramadhan (tarawih, tadarus, itikaf), dan (4) sebagai tempat penyelenggaraan penerangan haji.

b. Sebagai tempat untuk kegiatan muamalah yaitu berbagai kegiatan ibadah Islam yang dikerjakan dalam rangka kesempurnaan ibadah yang masih dalam batas-batas yang diwajibkan untuk agama dan menuju ketakwaan umat. Di masa Rasulullah saw, masjid menjadi pusat kebudayaan, yaitu berfungsi sebagai pusat pemerintah, pusat pendidikan, dan pusat urusan kemasyarakatan.

Di antara beberapa fungsi masjid yang dikemukakan oleh Gazalba di atas, fungsi masjid sebagai 
tempat penyelenggaraan penerangan haji dan fungsi masjid sebagai pusat pemerintahan tidak ditemukan pada masjid-masjid yang menjadi kasus dalam penelitian ini.

Fungsi masjid di Kalimantan Selatan kental dipengaruhi oleh aspek budaya lokal, karena Islam sendiri telah membudaya dalam wujud aktivitas kebudayaan yang diselenggarakan di masjid-masjid. Unsur-unsur agama Islam dan unsur-unsur kebudayaan berjalan bersamaan dalam rangka kesempurnaan ibadah sebagaimana fungsi lazimnya sebuah masjid, misalnya upacara aruh ganal yang setiap tahun diselenggarakan Suku Dayak Bukit. Setelah mereka memeluk agama Islam dan berganti nama menjadi Suku Banjar, acara ini tetap dilaksanakan dan disebut dengan bahaul. Jika aruh ganal bertujuan mendoakan para leluhur, maka bahaul berniat mendoakan kerabat/orang yang dihormati. Kegiatan bahaul dilaksanakan dengan memanjatkan doa-doa arwah yang ditujukan kepada Allah swt. Tujuan diadakannya acara-acara tradisi di masjid, karena dipercaya bahwa Nabi Muhammad saw dan arwah para ulama/kiai turut hadir dan turut berdoa bersama di majelis tersebut.

\section{Tipologi Ruang dan Wujud Masjid Tradisional Kalimantan Selatan}

Dari ketujuh kasus masjid yang telah dipilih tersebut, diperoleh informasi tipologi ruang (gambar 4) dan wujud bangunan (gambar 6).

\section{Tipologi Ruang}

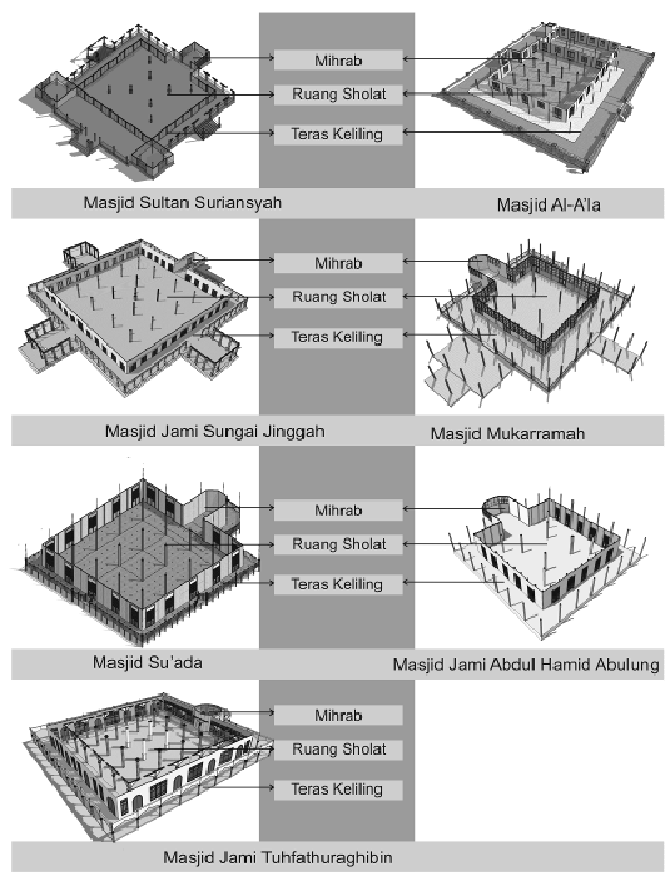

Gambar 4. Tipologi Ruang Masjid Tradisional Kalimantan Selatan (Sumber: Hasil Analisis, 2009)
Menurut Ching, space atau ruang adalah daerah tiga dimensi tempat dimana obyek dan peristiwa terdapat dan memiliki posisi serta arah yang relatif, terutama suatu bagian dari daerah tersebut yang dirancang sedemikian dalam hal yang telah diberikan atau untuk tujuan yang terpisah ${ }^{5}$. Khusus untuk ruang dalam masjid, Sumalyo menjelaskan bahwa elemen-elemen utama/pokok dari masjid adalah tempat shalat, mihrab (tanda arah kiblat), mimbar (tempat duduk memberikan ceramah), dan tempat wudhu. Minaret dan dikka adalah elemen pendukung atau pelengkap yang tidak selalu ada di setiap masjid $^{6}$.

Jenis ruang pada masjid tradisional Kalimantan Selatan sangat fungsional, karena hampir seluruh ruangan dapat dimanfaatkan secara fungsional. Ruang-ruang tersebut antara lain adalah mihrab, tempat shalat berjamaah, dan teras keliling. Ruangruang ini adalah ruang-ruang yang umumnya terdapat pada masjid tradisional di Kalimantan Selatan. Ruang mihrab berorientasi ke arah kiblat dan berfungsi sebagai tempat imam shalat, ruang shalat berjamaah berbentuk bujursangkar dan berfungsi sebagai tempat jamaah shalat, serta teras keliling yang berfungsi sebagai tempat shalat jika jamaah telah memenuhi ruang dalam masjid, sekaligus untuk menghindari tampias ketika hujan. Sementara itu, tempat bilal mengumandangkan adzan hanya dimiliki oleh dua dari tujuh masjid yang menjadi kasus penelitian ini.

Dalam pengalaman masyarakat Suku Banjar beribadah, terutama tempat beribadah Suku Dayak Bukit yang disebut dengan rumah balai, tidak dikenal jenis ruang-ruang yang ada pada masjid tradisional ini. Jadi, jenis ruang pada masjid tradisional Kalimantan Selatan ini tidak mendapatkan pengaruh dari Suku Dayak Bukit dalam beribadah.

Kemungkinan besar, masjid-masjid ini dipengaruhi oleh tipe masjid yang ada di Pantai Utara Jawa. Hal ini dikarenakan, jika dilihat dari sudut sejarah masjid pertama yang didirikan di daerah ini pada tahun 1525 Masehi, pendirinya adalah seorang panglima perang Kerajaan Demak sekaligus imam pertama masjid, Syekh Syarif Abdurrahman atau Khatib Dayyan, dan juga perancang bangunan ini, Aria Malangkang, juga berasal dari kerajaan yang sama. Kemungkinan besar, pengalaman Khatib Dayyan dan Aria Malangkang lebih berperan dalam terbentuknya ruang-ruang pada masjid pertama ini. Meski begitu, masjid yang didirikan ini tidak sama persis dengan Masjid Kerajaan Demak. Perbedaan yang terlihat antara lain adalah, masjid tradisional Kalimantan Selatan tidak memiliki pendhapa dan minaret, sementara masjid di Pantai Utara Jawa memiliki kedua ruang tersebut.

Terdapat pula kemungkinan bahwa pada saat pertama didirikan, jenis ruang yang didirikan adalah ruang-ruang yang fungsional saja. Fungsi yang ada 
sangat sederhana, yaitu sebagai tempat untuk melangsungkan shalat berjamaah, karena itulah ruangruang yang ada juga menjadi sangat fungsional, yaitu hanya ruang-ruang yang benar-benar diperlukan saja. Alasan ini juga sama seperti pada pendirian masjid pertama di dunia oleh Nabi Muhammad saw. Menurut Wiryoprawiro, pada pembangunan Masjid Quba dan Masjid Nabawi di Madinah oleh Nabi Muhammad saw, terdapat pola awal yang cenderung mengarah pada bentuk yang fungsional sesuai kebutuhan, yaitu untuk shalat berjamaah, berbentuk persegipanjang, sebagian berupa halaman (shaan) dan sebagian berbentuk bangunan (liwan) ${ }^{7}$.

\section{Tipologi Wujud Bangunan}

Menurut Ching, wujud merupakan sisi luar karakteristik atau konfigurasi permukaan suatu bentuk tertentu ${ }^{8}$. Wujud juga merupakan aspek utama dimana bentuk-bentuk dapat diidentifikasikan dan dikategorisasikan. Wujud masjid tradisional berbeda dengan bangunan tradisional lainnya yang ada di Kalimantan Selatan. Perbedaan wujud ini dapat dilihat pada bentuk denah dan bentuk atap. Perbedaan wujud ini menyebabkan masjid mudah dikenali.

Bentuk denah bangunan (rumah) tradisional Kalimantan Selatan berbentuk cacak burung, sedang denah masjid berbentuk bujursangkar atau persegi. Semua kasus dalam penelitian ini memiliki denah berbentuk persegi. Baik rumah maupun masjid tradisional Kalimantan Selatan ini berwujud simetris.
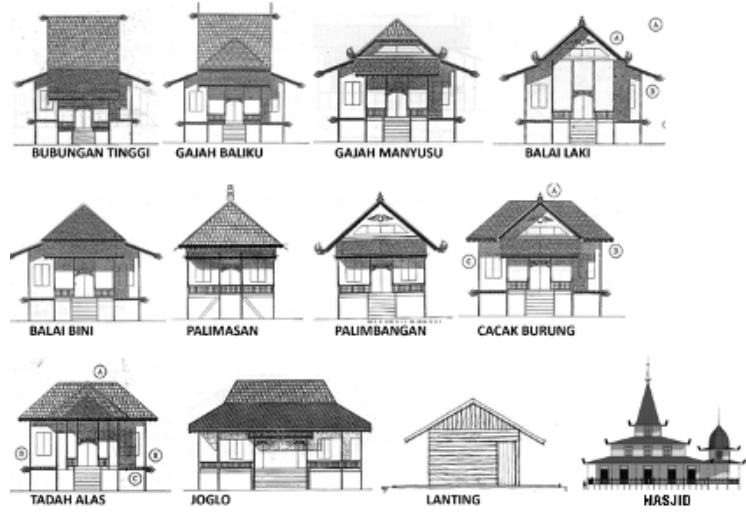

Gambar 5. Wujud-Wujud Arsitektur Tradisional Kalimantan Selatan (Sumber: Diolah dari Seman, 2000)

Untuk bentuk atap, setiap bangunan tradisional di Kalimantan memiliki bentuk atap yang berbedabeda, tergantung pada penghuni dan peruntukan bangunan tersebut (Gambar 5). Dari bentuk ataplah bangunan-bangunan yang ada memiliki identitas masing-masing. Seman dan Irhamna mengungkapkan bahwa atap bubungan tinggi adalah untuk Rumah Bubungan Tinggi yang ditempati oleh raja, atap gajah baliku untuk Rumah Gajah Baliku yang ditempati kerabat raja, atap gajah mayusu untuk Rumah Gajah Mayusu yang ditempati warit raja, atap balai laki untuk Rumah Balai Laki sebagai tempat punggawa, mantri, dan prajurit, atap balai bini untuk Rumah Balai Bini sebagai tempat bagi para putri, atap palimasan untuk Rumah Palimasan sebagai tempat bagi bendaharawan kerajaan, atap palimbangan untuk Rumah Palimbangan sebagai tempat bagi ulama/kiai, dan sebagainya9.

Bentuk atap rumah tradisional Kalimantan Selatan umumnya merupakan perpaduan antara atap pelana dan atap perisai tidak bertumpang, sedangkan bentuk atap masjid berupa limasan dan bertumpang tiga. Perwujudan atap limasan dengan sudut runcing $60^{\circ}$ dan sudut tumpul $20^{\circ}$, serta bertumpang tiga dengan hiasan pada puncak atapnya merupakan simbol dari burung enggang yang berada/bertengger di atas pohon hayat yang merupakan simbol dari bangunan masjid secara keseluruhan (Gambar 6). Selain bertumpang tiga, masjid tradisional Kalimantan Selatan memiliki dua atap yang menaungi dua ruang, yaitu atap untuk ruang shalat dan atap untuk ruang imam. Kedua atap ini memiliki konsep masing-masing.

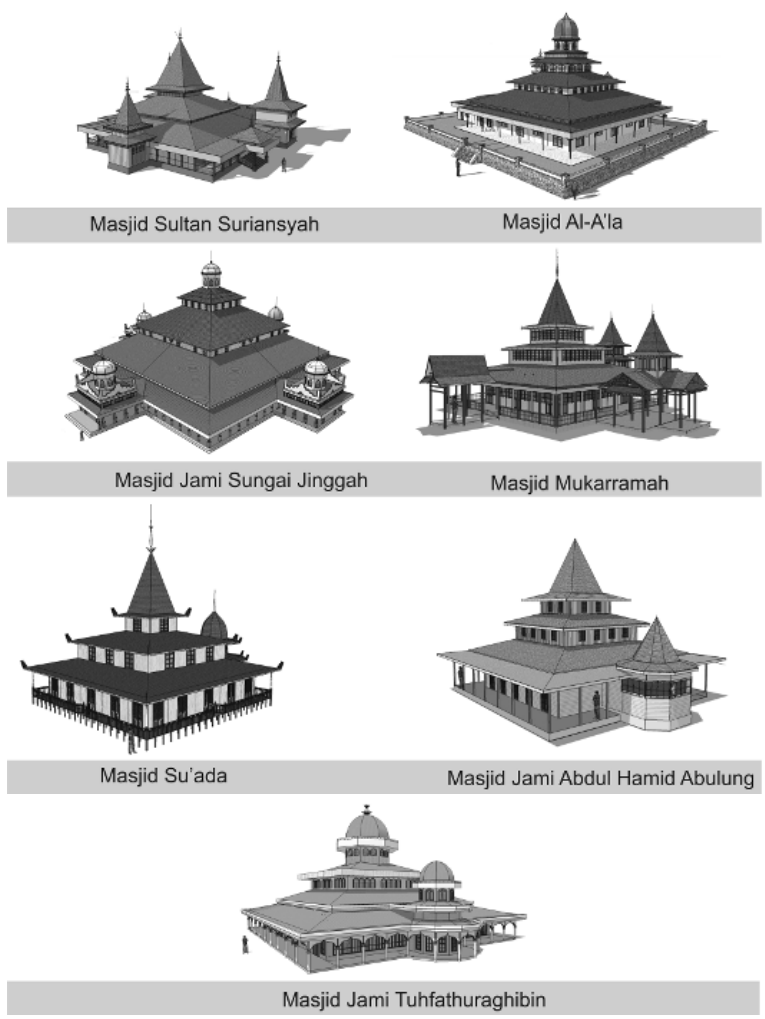

Gambar 6. Tipologi Wujud Masjid Tradisional Kalimantan Selatan (Sumber: Hasil Analisis, 2009)

Dalam mitos langit, bumi, dan manusia, ajaran Kaharingan mengakui adanya pohon hayat dan burung enggang yang bertengger melahirkan konsep serba dua, yaitu jantan-betina, siang-malam, teranggelap, atas-bawah. Pohon hayat dan burung enggang yang bertengger, dalam mitologi Suku Dayak merupakan pohon yang diyakini sebagai pohon pemersatu 
Suku Dayak di Kalimantan ${ }^{10}$. Simbol pohon hayat dan burung enggang yang bertengger digunakan pada wujud masjid tradisional Banjar secara keseluruhan. Dari pondasi hingga puncak atap merupakan perwujudan dari pohon hayat, sedangkan pataka/patala (hiasan pada puncak atap masjid) merupakan perwujudan dari simbol burung enggang yang bertengger. Bentuk burung enggang tidak diperbolehkan dalam syari'at Islam. Oleh karena itu, bentukan burung enggang distilir menjadi bentuk sulur-suluran tanaman, tetapi tetap dimaknai sebagai burung enggang.

Selain merupakan perwujudan pohon hayat, wujud atap masjid tradisional Kalimantan Selatan ini juga mendapat pengaruh dari masjid-masjid di Pantai Utara Jawa, karena penyebaran Islam dan pendirian masjid pertama di Kalimantan Selatan dilakukan oleh ulama dari Kerajaan Demak. Jika demikian, maka dalam konsep atap masjid Kalimantan Selatan yang bertumpang tiga, terkandung konsep atap tumpang masjid Jawa, yaitu memiliki komposisi yang mirip meru.

Dalam tulisan Budi, disebutkan bahwa peneliti Belanda, K. Hidding, di tahun 1933 dalam tulisannya yang berjudul "Het bergemotief in eenige godsdienstige verschijnselen op Java", menyebutkan bahwa atap masjid Jawa merupakan wujud dari bentuk gunung yang disucikan ${ }^{11}$. Pendapat ini juga didukung oleh ilmuwan Belanda lain, yaitu H. J. de Graff dalam tulisannya "De Oorsprong der Javaanse Moskee", yang menyebutkan bahwa bentuk atap masjid Jawa memang diturunkan dari bentuk gunung, karena merupakan suatu bentuk yang suci dan sakral dalam tradisi Hindu-Jawa. Selanjutnya Pijfer dalam Budi juga menegaskan hal ini dari sudut pandang ilmiah dalam makalahnya yang berjudul "The Minaret in Java". Menurut Pijfer, atap yang bertumpuk dan mengerucut pada satu titik seperti itu (masjid jawa) mengidentifikasikan orisinalitas dari bangunan pra-Islam, yaitu bentuk meru ${ }^{12}$. Atap tumpang lima pada Masjid Agung Banten dan Masjid Jepara di abad ke-17 adalah kelangsungan dari meru. Meskipun terdapat banyak pendapat tentang asal-usul atap bertumpang pada masjid, di akhir tulisannya Bambang Setia Budi menyimpulkan bahwa hal ini masih memerlukan bukti-bukti yang konkret, karena hal ini masih diperdebatkan hingga sekarang.

Sementara itu, peneliti lain, Ir. H. Maclaine Pont menggunakan pendekatan arsitektur tradisional Jawa dan relief Borobudur untuk meneliti asal-usul perkembangan struktur bangunan masjid yang bertumpang ${ }^{13}$. Hasilnya adalah bahwa bentuk masjid bermula dari struktur tenda, kemudian berkembang menjadi struktur bangunan Joglo Lambang Sari, kemudian berkembang menjadi Joglo Lambang Gantung, kemudian pada perkembangan selanjutnya berubah menjadi Joglo Ngastina Lambang Gantung, dan akhirnya berkembang menjadi struktur bangunan masjid dengan tiang pusat, dan kemudian mengalami perkembangan menjadi masjid tidak bertiang pusat. Proses perkembangan ini dapat dilihat pada gambar berikut.

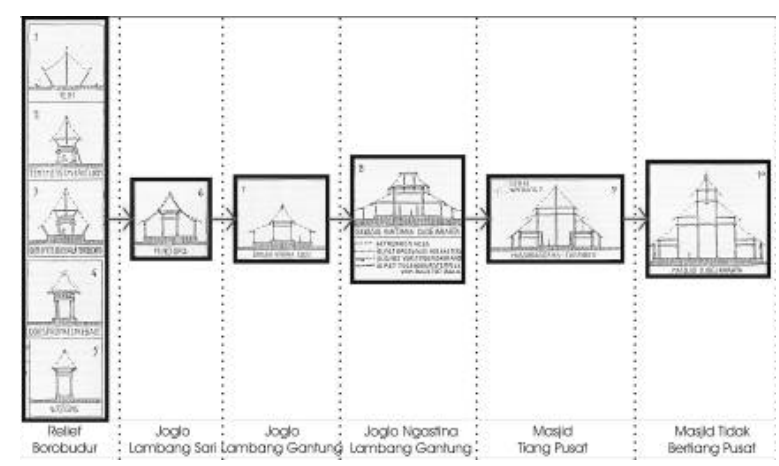

Gambar 7. Asal-usul Perkembangan Struktur Bangunan Masjid Tumpang (Sumber: Pont dalam Wiryoprawiro, 1986)

Jadi, meski belum diketahui secara pasti asalusul struktur masjid bertumpang, dapat dipastikan bahwa atap tumpang pada masjid tradisional Kalimantan Selatan mendapat pengaruh dari penyebar agama Islam ke Kalimantan Selatan, yaitu Kerajaan Demak. Hal ini diperkuat dengan tidak dikenalnya atap tumpang pada arsitektur tradisional Kalimantan Selatan lainnya. Walaupun demikian, di balik konsep atap tumpang yang ada di Kalimantan Selatan terkandung simbol pohon hayat, sehingga bentuk atap tumpangnya berbeda dengan bentuk atap tumpang yang ada pada masjid-masjid di Pantai Utara Jawa. Perbedaannya terletak pada sudut kemiringan atap di tingkat paling atas. Pada masjidmasjid di Pantai Utara Jawa cenderung bersudut tumpul, sedangkan pada masjid-masjid di Kalimantan Selatan atap cenderung runcing dengan sudut kemiringan $60^{\circ}$ sampai $75^{\circ}$ (Gambar 8).

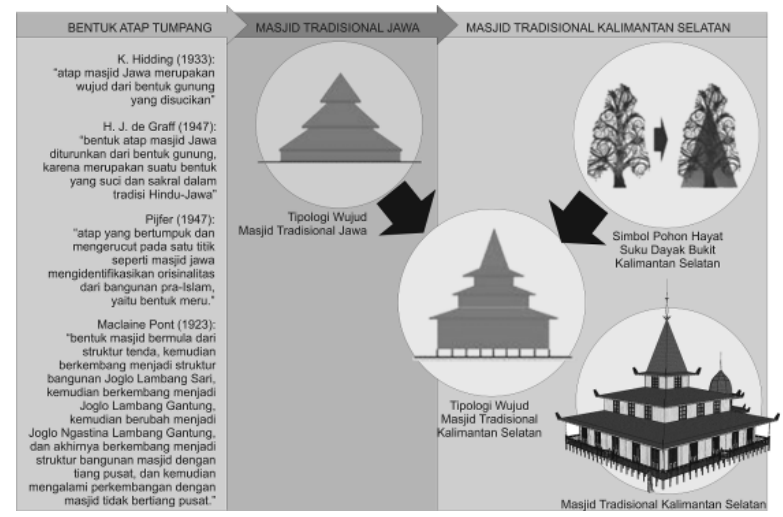

Gambar 8. Asal Mula Wujud Masjid Tradisional Kalimantan Selatan (Sumber: Hasil Analisis, 2009)

Berdasarkan hasil analisis di atas, diketahui bahwa wujud Masjid Tradisional Kalimantan Selatan dipengaruhi oleh wujud atap tumpang yang berasal 
dari masjid di Pantai Utara Jawa, namun mengandung pula konsep budaya lokal, yaitu pohon hayat.

\section{Penutup}

Dari penelitian yang telah dilakukan, dapat disimpulkan bahwa tipologi ruang masjid Kalimantan Selatan terdiri dari (1) ruang mihrab yang berorientasi ke arah kiblat dan berfungsi sebagai tempat imam shalat, (2) ruang shalat yang berbentuk bujur sangkar dan berfungsi sebagai tempat jamaah shalat, serta (3) teras keliling yang berfungsi sebagai tempat shalat jika jamaah telah memenuhi ruang dalam, sekaligus untuk menghindari tampias jika hujan. Selain itu, juga disimpulkan tentang tipologi wujud masjid tradisional Kalimantan Selatan, yaitu atap berbentuk perisai bersudut runcing $\left(60^{\circ}\right)$ dan atap landai $\left(20^{\circ}\right)$, denah berbentuk bujursangkar atau persegi, wujud keseluruhan merupakan simbolisasi dari pohon hayat, serta terdapat simbol burung enggang di puncak atap masjid (patakal patala). Kedua simbol ini merupakan simbol identitas dalam mitologi Suku Dayak.

Dari hasil studi di lapangan, salah satu kasus yang dapat menjadi referensi mengenai bagaimana tipologi ruang dan wujud masjid tradisional Kalimantan Selatan sesungguhnya, adalah Masjid Su'ada Wasah. Hal ini dikarenakan bangunan masjid ini merupakan satu-satunya masjid yang masih mempertahankan keasliannya, baik kondisi, konstruksi, tata ruang, maupun ornamennya. Berikut adalah gambar tipologi ruang dan wujud Masjid Su'ada Wasah sebagai referensi bagi pihak-pihak yang berkepentingan (Gambar 9).

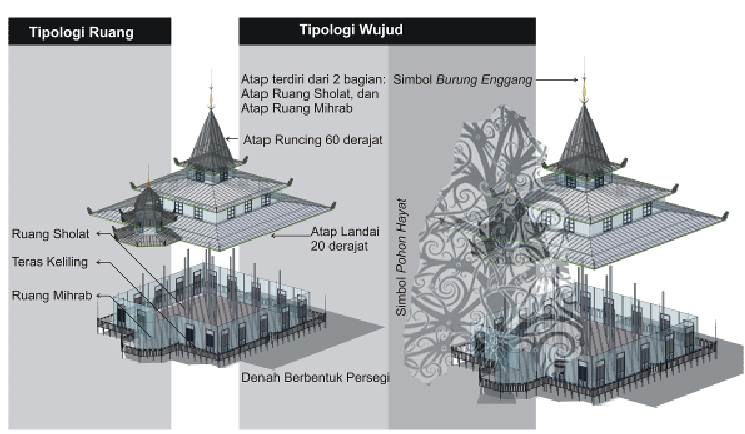

Gambar 9. Tipologi Ruang dan Wujud Masjid Tradisional Kalimantan Selatan yang Terwakili dalam Arsitektur Masjid Su'ada Wasah (Sumber: Hasil Analisis, 2009)

Dari temuan penelitian ini juga disarankan dilakukannya penelitian lanjutan, terutama yang menyangkut penelitian terhadap objek yang lebih detail dari Masjid Tradisional Kalimantan Selatan, atau penelitian terkait lainnya. Selain itu, disarankan pula kepada pihak-pihak terkait agar dapat mempertimbangkan tipologi ruang dan tipologi wujud masjid tradisional Kalimantan Selatan menjadi referensi dalam upaya pembangunan kembali atau rekonstruksi atau rehabilitasi bangunan-bangunan, terutama bangunan masjid tradisional di Kalimantan Selatan.

\section{Referensi}

1 Nangkula Utaberta. 2004. Rekonstruksi Pemikiran, Filosofi dan Perancangan Arsitektur Islam Berbasiskan Al-Qur'an dan Sunnah.

2 Bambang Setia Budi. 2005. Jalan Panjang Rumah Tuhan. Majalah Gatra Edisi Khusus Lebaran: Geliat Negeri Sejuta Masjid. Jakarta: PT. Era Media Informasi

3 Bani Noor Muchammad, Gunadi Kasnowihardjo \& Naimatul Aufa. 2006. Melacak Arsitektur Kraton Banjar. Laporan penelitian tidak diterbitkan. Banjarmasin: Universitas Lambung Mangkurat

4 Sidi Gazalba. 1962. Masdjid Pusat Ibadat dan Kebudajaan Islam. Djakarta: Pustaka Antara

5 Francis DK. Ching. 2000. Arsitektur: Bentuk, Ruang dan Susunannya. Jakarta: Erlangga

6 Yulianto Sumalyo. 2002. Arsitektur Masjid. Yogyakarta: Gadjah Mada Unversity Press

7 Zein M. Wiryoprawiro. 1986. Perkembangan Arsitektur Masjid di Jawa Timur. Surabaya: PT. Bina IImu

8 Francis DK. Ching. 2000. Arsitektur: Bentuk, Ruang dan Susunannya. Jakarta: Erlangga

9 Syamsiar Seman \& Irhamna. 2001. Arsitektur Tradisional Banjar Kalimantan Selatan. Banjarmasin: Ikatan Arsitek Indonesia Daerah Kalimantan Selatan

10 Soewondo. 1983. Sistem Kesatuan Hidup Setempat Daerah Kalimantan Selatan. Jakarta: Departemen Pendidikan dan Kebudayaan

11 Bambang Setia Budi. 2005. Jalan Panjang Rumah Tuhan. Majalah Gatra Edisi Khusus Lebaran: Geliat Negeri Sejuta Masjid. Jakarta: PT. Era Media Informasi

12 Pijfer dalam Bambang Setia Budi. 2005. 'The Minaret in Java'. Dalam Jalan Panjang Rumah Tuhan. Majalah Gatra Edisi Khusus Lebaran: Geliat Negeri Sejuta Masjid. Jakarta: PT. Era Media Informasi

13 Ir. H. Maclaine Pont dalam Zein M. Wiryoprawiro. 1986. Perkembangan Arsitektur Masjid di Jawa Timur. Surabaya: PT. Bina Ilmu 